\title{
Towards Maintaining Peacefulness of the Sea: Legal Regime Governing Maritime Safety and Security in Nigeria
}

\author{
Ekundayo Oluwaremilekun Babatunde1, Mutiat Mobolanle Abdulsalam² \\ ${ }^{1}$ Department of Public and International Law, Faculty of Law, Kola Daisi University, Ibadan, Nigeria \\ ${ }^{2}$ Department of Private and Business Law, Faculty of Law, Al-Hikmah University, Ilorin, Nigeria \\ Email: oluekundayo@yahoo.com,mutiatabdulsalami@yahoo.com
}

How to cite this paper: Babatunde, E. O., \& Abdulsalam, M. M. (2021). Towards Maintaining Peacefulness of the Sea: Legal Regime Governing Maritime Safety and Security in Nigeria. Beijing Law Review, 12, 529-559. https://doi.org/10.4236/blr.2021.122029

Received: June 30, 2020

Accepted: May 29, 2021

Published: June 1, 2021

Copyright (๑) 2021 by author(s) and Scientific Research Publishing Inc. This work is licensed under the Creative Commons Attribution International License (CC BY 4.0).

http://creativecommons.org/licenses/by/4.0/ (c) (i) Open Access

\begin{abstract}
This study examined the development of international and municipal laws on maritime safety and security and identified the challenges undermining the efficiency of the provisions at combating security threats within the Nigerian maritime space. The study relied on primary and secondary sources of information. The primary sources included the United Nations Convention on the Law of the Sea (UNCLOS) 1982, Convention for the Suppression of Unlawful Acts against the Safety of Maritime Navigation 1988, the Safety of Lives at Sea (SOLAS) Convention 1974, municipal legislations and Judicial decisions. While the secondary sources included books, journal articles, conference proceedings and the internet. It was found that there is an array of international laws addressing maritime safety and security. It was further found that the effectiveness of these international maritime laws in Nigeria is undermined by inadequate implementation traceable to socio-legal, institutional and political issues in the country. The study recommends adoption of functional legal, institutional and policy measures to address the various implementation challenges, address maritime safety and security threats in the $\mathrm{Ni}$ gerian maritime domain and aid the maximization of the nation's maritime resources to facilitate development.
\end{abstract}

\section{Keywords}

Maritime Security, Threats to Maritime Security, Law of the Sea

\section{Introduction}

Maritime security is a crucial aspect of maritime practice and administration, which is central to the full realization of the immense potentials of the mari- 
time industry. The availability of a secured maritime domain which engenders international peace and stability is at the heart of maximizing the full potentials of the maritime industry. Maritime practice and administration can only be maximized to meet the demands of the growing global population, for food, employment, energy and marine bio-diversity if the maritime space is secured (Gilpin, 2007).

The subject of maritime security from the perspective of a state is concerned with protection of the nation's maritime assets, space and practices from all forms of man induced threats. It involves preservation of national territorial integrity, peace and order within the nation's maritime domain by preventing and combating all forms of criminal activities through internal and external mechanisms. From the global perspective, maritime security is concerned with elimination of all forms of maritime crimes, including trans-national organized crime perpetrated through the maritime space capable of threatening the maritime environment and inhibiting realization of the blue economy (Bueger \& Edmunds, 2017). Maritime security is preserved through adoption and implementation of legal and policy measures targeted at protecting national integrity and promoting good order at sea. By its very nature, the ocean and its resources have no transboundary limits, likewise the various threats to maritime security are transnational in nature. As a result, they are addressed through transnational laws at the regional and international arena.

The use of the ocean for transportation of goods and passengers is as ancient as human civilization. With increased use of the sea from bulk carriage, there was need for adoption of codes to regulate peaceful use of the sea. The earliest codified law of the sea being Rhodian Sea Law for regulation of Mediterranean trade and subsequently there medieval sea codes such as the Laws of Wisby were enacted. However, as seaborne trade grew so also did piracy and other forms of security threats (Gedecho, 2013). Over the century, the law of the sea has continued to evolve to address emerging and contemporary threats. Today, the United Nations Convention on the law of the Seas (UNCLOS) (1982) (Koh, $1985)$ is the principal international instrument on maritime practice and administration. UNCLOS has evolved over decades, from the Geneva Convention of 1958 (UNCLOS I) to the UNCLOS II which failed to result in an international agreement. The 1982 UNCLOS III set the jurisdictional regime for international maritime practice and administration, necessitated by the need to address the problem of maritime boundary disputes among states, which was rampant at the time of its coming into place (Treves, 1958).

Insecurity at sea is traditionally a major challenge which interferes with the enjoyment of socio-economic benefits of the marine ecosystem. Historically, the sea is recognized as a danger zone. As far back as the $2^{\text {nd }}$ Century BC, activities of pirates were already rampant in the Mediterranean as there was no major naval power in the region. The severity of piracy increased as Romans procured 
slaves from pirates, as such the activities of pirates disrupted the wheat trade as the produce was being transported between Egypt and Italy. Pirates later took over the Mediterranean Sea, making Cilicia their base. The Cilicia pirates were notorious for their kidnapping of crews from ships as hostages who were later sold into slavery. Among their most famous hostages was Julius Ceaser (Adam, 2007). Today, threats to maritime security go beyond piracy but also include other acts of violence at sea which spreads across continents. The major forms of threat to maritime security are piracy, armed robbery against ships, and IUU fishing. Although there are other forms of threats to maritime security such as trans-national organized crime, maritime terrorism, kidnapping for ransom, dumping of toxic wastes, trade in Small Arms and Light Weapons (SALW), illegal trade in narcotic drugs and psychotic substances. However, Piracy and armed robbery at sea remain the most notorious forms of threat to maritime security. In 2008 for instance, the global shipping industry reported 293 cases of piracy and armed robbery against ships, in the course if which 49 vessels were hijacked, and $889 \mathrm{crew}$ members were taken as hostages (International Maritime Bureau, 2008). Similarly, between 2006 and 2010, the shipping community has recorded huge losses to maritime insecurity, running into millions of dollars' worth of cargo and money paid as ransom for the release of kidnapped persons. Thus, from the Mediterranean Ocean, to the Indian Ocean, the East China Sea, South China Sea and the Atlantic Ocean, maritime insecurity remains a universal problem confronting the global community (ICC Commercial Crime Services, 2011).

The GoG is one of the globally recognized hot-spots for maritime insecurity, nonetheless the relentless efforts being made over the years, at the national, regional and international arena, to tackle the problem. In 2017, the GoG region recorded 97 incidents of pirate attacks which affected 1726 seafarers and led to total loss of about \$13.2 million US Dollars, which is the second worst rate of maritime insecurity compared to other regions (Esposito 2018). Within the GOG, the West African water is known to be particularly dangerous. The frequency of attacks, in West African waters has been on the increase, from 54 incidents in 2015 to 112 incidents in 2018. Majority of the attacks take place in Nigeria, around Brass in Bayelsa state, Bonny in Rivers state and Lagos state of Nigeria, and a few others were in neighboring West African states including Benin, Ghana, Congo, and Cameroon (Udodiong, 2019). According to the International Maritime Bureau (IMB), the global maritime community recorded 75 incidents of hostage taking and kidnaping for ransom in 2019, out of which 62 occurred in West Africa, and 8 out of the 9 incidents of attack on vessels was within the Nigerian waters. The nation recorded 21 incidents in the first and second quarter of 2019 (Bartlett 2019). Meanwhile, Nigeria has been a signatory to the UNCLOS convention since 1986 and the Convention assumed the force of law in 1994. Nigeria also domesticated UNCLOS through the Suppression of Piracy and Other Maritime 
Offence Act (SUPMAO) in 2019.

However, despite the robust provisions of UNCLOS, contemporary maritime practice and administration are still confronted with serious security issues. In West Africa generally, and Nigeria in particular, maritime security challenges remain major clog to the realization of the much desired blue economy. The provisions of UNCLOS have proven to be inadequate for addressing the numerous emerging maritime security issues like maritime terrorism, trafficking of migrants, Port security, and transmission of Weapons of Mass Destruction (WMD) and jurisdictional issues which appears to render the UNCLOS regime outdated. Although there are supporting international agreements which appear to fill-in for the limitations of the UNCLOS regime, the persistence and severity of safety and security challenges point to the limited success. The ever-growing maritime security challenges in the Nigerian waters necessitates a look at UNCLOS security provisions to determine the lacuna contained therein which has made its implementation to achieve set security objectives in the Nigerian waters difficult (Ukeje \& Ela, 2013). Existing studies address the Nigerian maritime space with emphasis on insecurity in the Niger Delta region of Nigeria (Raymond \& Ofosu-Boateng, 2017). However, there is a dearth of literature on the evolution of the law of the sea to ascertain the inherent limitations in the current international maritime regime, its effect on the efficiency of maritime security provisions and the challenges undermining its efficiency in Nigeria.

\section{Evolution of International Maritime Law}

Before the modern era, as far back as the $1^{\text {st }}$ millennium BC, mankind relied on the sea as an ancient channel for transporting goods and passengers. Merchants relied on the Ocean for conveying bulk goods designated for international trade. In those early days, there were no formal rules governing the use of the ocean and its resources. The need for set-rules on the use of the sea led various empires to develop some form of maritime codes. The ancient law of the sea includes the Rhodian Sea Laws, drafted in 900B.C, Laws of Wisby adopted in the Baltic Port, Laws of Hansa Towns of the German league, the French Island's Laws of Oleron which were both inspired by Consolato del Mare (Vitzthum, 2003).

Upon the formation of Comité Maritime International (CMI) in 1897, the CMI under the auspices various United Nations (UN) bodies such as the Intergovernmental Maritime Organization (IMO) took steps to aid the adoption of uniform maritime laws. The CMI also facilitated the drafting of international instruments like the Hague Rules, the Hague Visby Rules (Bin-Hasan, 2007) and the Salvage Convention (Ekhator, 2016) among others.

The first codified multilateral instrument on the law of the sea was the 1958 Geneva Conventions on the Law of the Sea. The conventions were the outcome of the first United Nations Conference on the Law of the Sea held in Geneva 
Switzerland between $24^{\text {th }}$ February and $27^{\text {th }}$ April 1958. At the Conference, the four Conventions on the Law of the Sea and an optional protocol were opened for signing. These instruments were the Convention on the Territorial Sea and the Contiguous Zone (CTS); the Convention on the High Seas (CHS); the Convention on Fishing and Conservation of the Living Resources of the High Seas (CFCLR); the Convention on the Continental Shelf (CCS); and the Optional Protocol of Signature concerning the Compulsory Settlement of Disputes (OPSD) (Treves, 2020). The unresolved issues in the course of the conference necessitated the Second United Nations Conference on the Law of the Sea, held in Geneva, Switzerland between $16^{\text {th }}$ March and $26^{\text {th }}$ April 1960. However, the second UNCLOS was unsuccessful.

\section{The United Nations Convention on the Law of the Sea (UNCLOS III)}

The coming into being of the third United Nations Convention of the Law of the Sea (UNCLOS III) was initiated by the speech delivered by Arvido Pardo at the United Nations General Assembly in 1967. This marked the beginning of efforts to replace the GCLOS has now been replaced by UNCLOS III. However, the latter instrument does not adopt all the provision of the former, while some of the adopted provisions were subjected to modifications following negotiations among state parties (Boyle, 2005). The 1982 United Nations Convention on the Law of the Sea (UNCLOS) is the principal international instrument governing maritime practice and administration, otherwise known as 'the constitution for the oceans'. UNCLOS was negotiated at the United Nations Third Law of the Sea Conference, the negotiations were concluded in 1982 at Montego Bay in Jamaica, but the convention only entered into force in 1994. It codified the provisions of the preceding instruments, 1958 Geneva Convention on the Law of the Sea (GCLOS), on the status of territorial sea, contiguous zone, continental shelf and the high sea. It also introduced new legal regime relating to continental shelf, seabed, and Ocean floor as a common heritage of mankind. It specify the legal limits and regime that will govern coastal state claims, including 12 nautical miles of territorial sea, 200 miles of Exclusive Economic Zone and 350 nautical miles for extension of continental shelf (Ahmed, 2017).

\section{Challenges Undermining Effective Implementation of UNCLOS Security Provisions in Nigeria}

\subsection{Issues Relating to the Domestication of UNCLOS}

Nigeria is a federal state which operates based on the dualist principle of international law. The implication being that an international instrument or treaty which has been signed and ratified by the Nigerian state can only be applicable upon domestication. Section 12(1) (2) of the 1999 Constitution which provides:

1) No treaty between the Federation and any other country shall have the 
force of law to the extent to which any such treaty has been enacted into law by the National Assembly. 2) The National Assembly may make laws for the Federation or any part thereof with respect to matters not included in the he Exclusive Legislative List for the purpose of implementing a treaty (CFRN 1999).

This position of the constitution has been buttressed by the Nigerian courts in several judicial pronouncements. In the case of Abacha v. Fawehinmi [2000] 6 NWLR [pt 660] 228-288, the Supreme Court held that a treaty is not binding until and unless the National Assembly incorporates it into the Nigeria law. Nigeria ratified UNCLOS in 1986, however, it is not until 33 years later, in 2019 that UNCLOS was expressly domesticated. UNCLOS was domesticated via the Suppression of Piracy and other Related Offences Act 2019. Whereas domestication of UNCLOS is a welcomed development, the act only grants UNCLOS umbrella domestication without going into the nitty-gritty of provisions of the convention which requires clarification and which a state signatory may improve upon through the domesticated version of the convention. The SUPMAO is an instrument targeted at giving effect to the provisions of UNCLOS, the Convention for the Suppression of Unlawful Acts against the Safety of Maritime Navigation (SUA) 1988 and its protocols. Although it is aimed at suppressing piracy, armed robbery and other unlawful acts in the maritime space, against ships, aircrafts, fixed or floating platforms, it failed to obvious limitations of the safety and security provisions of UNCLOS. These include:

The nation's attitude towards treaty domestication is extremely poor. Since accession to UNCLOS in 1986, Nigeria only recently domesticated UNCLOS in 2019. Also, the domestic instrument through which UNCLOS was made law did not specifically address UNCLOS. Rather, it only gave an umbrella domestication without specifically adaption the provisions of the convention to meet the need of the nation or improving of the various limitations in the provisions of UNCLOS. Provisions such as piracy control, innocent passage, pollution, transit of noxious substances needs to be adapted to the domestic rules and policies.

\subsection{Security Challenge Posed by the UNCLOS Innocent Passage Regime}

It has been argued that innocent passage is not a right of the flagged ship, rather it is a privilege which the coastal state prepares itself to condone or tolerate. Whereas UNCLOS expressly specify passage which is not innocent, it makes it difficult for a coastal state to deny a vessel innocent passage. For instance, a vessel that will be prevented from innocent passage must have committed an act that is prejudicial. However, certain acts despite against the interest of the coastal state, such as pollution resulting from poor construction are not regarded as pre-judicial per-se. it has been argued that UNCLOS provisions on innocent 
passage grants excessive protection to the coastal state. For instance, nearly all forms of innocent passage by a military vessel will amount to threat to the Coastal state and therefore be perceived as prejudicial (UNCLOS Article 19(2). For these reasons, several western coastal state impose the condition precedent that a vessel intending to enjoy innocent passage should issue prior notice to the coastal state and obtain authorization before proceeding to enjoy such passage. Although the requirement of prior-notice and authorization is not incorporated into UNCLOS, the fact that it is popularly practiced by nations in the west, especially where the vessel enjoying innocent passage is a warship, grants it the status of customary international law. Moreover, the condition of prior notice and authorization as a condition precedent to the exercise of innocent passage may also be validated as part of the laws and regulation of the coastal state which the vessel is required to comply with under Article 21, if codified. Where such condition is not codified, it will amount to undue hindrance of innocent passage which the coastal state is prohibited from resorting to by Article 24 .

Thus, the grant of umbrella ratification for UNCLOS without re-examining and improving on specific provisions such as condition-precedent to the grant of innocent passage. There are several aspects of innocent passage which needs to be clearly defined and there are issues to be clarified through the enactment off regulations. Further, a coastal state is authorized to adopt laws regulating various aspects of innocent passage including safety of navigation, regulation of marine traffic, protection of navigational aids, facilities, cables and pipelines, conservation of marine living resources, preventing infringement of fishing regulations, and control of pollution. The coastal stat also has the right to adopt laws regulating marine scientific research and hydrographic survey, and preventing the infringement of the regulations on custom, immigration, fiscal activities, and sanitary regulations (UNCLOS Article 29(2). Another issue that needs to be clarified is the conditions to be met before a coastal state can exercise both civil and criminal jurisdiction against an earring vessel while on innocent passage. First the crime of civil wrong must directly affect the coastal state, or peace and order within the territorial waters, and the vessel must have left the territorial sea into internal waters in case of civil jurisdiction and outside the territorial waters in case of criminal jurisdiction. This gives a large room for a vessel which commits a crime during innocent passage and its passengers to escape liability. This also adds to the threat of insecurity as spontaneous actions cannot be taken by the coastal state to arrest or prosecute crime or civil wrong in good time. Failure on the part of the Nigerian state to put in place necessary by laws for these purposes creates avenue for insecurity and uncontrolled perpetration of transnational organized crime by vessels under acclaimed innocent passage. Generally, the responsibility falls on coastal state to secure its waters, yet the conditions imposed by UNCLOS are too stringent for this to be achieved. The innocent passage of warships and non-commercial warships also needs to be properly regulated. 


\subsection{Failure to Address Security Challenge of the UNCLOS Continental Shelf Regime}

The EEZ and the Continental shelf are two closely connected parts of the sea. The EEZ regime has a limit of 200 nautical miles (Article 57), On the other hand the continental shelf regime may extend beyond 200 nautical miles, to 350 nautical miles from the baseline (Article 76(4-6)). The implication of extension of continental shelf boundary for maritime security is the expansion of the state's sovereign authority to police and secure the outer limits of continental shelf up to 350 nautical miles. Article 76 of UNCLOS specifies the procedure for extension of continental shelf boundary beyond 200 nautical miles. The coastal state shall delimit this extension either by drawing straight lines, not exceeding length of 60 nautical miles connecting fixed points, defined by coordinate of longitude and latitude (Article 76(7)). Proper notice shall be given to Commission on Limits of Continental Shelf on basis of equitable geographical representation. Thereafter the commission shall make recommendations on the delimitation and such recommendations are binding. A further technical which shall support the claim, to be submitted to the UN General Secretary is a premium on the determination of the thickness of the sedimentary rocks in the seabed, calculation of seafloor gradients, bathymetry and features of natural component of the continental margin. These are complex legal requirements which are dependent on scientific calculation for its determination. Considerations must cover continental shelf, continental slope and continental rise. The commission shall ensure full compliance with these requirements before a coastal state' application can be granted. Similarly, such application shall not be granted where there is an existing dispute over the delimitation between the applicant and neighboring states.

Expansion of the external limits of the continental shelf requires expertise skill of legal practitioners and scientists using specialized equipment. This will have serious financial implication for the coastal states concerned. In case of Nigeria, the nation may not be able to meet these requirements for the delimitation. This places a restriction on the area within which the nation enforces security provisions and extends the area from which threats may spread into the domestic maritime space. On the flip side, Nigeria lacks adequate equipment for policing the nation's maritime space. At present, there are no adequate equipment, facilities and manpower to survey and police the nation's territorial waters. In addition, the $\mathrm{NN}$ and other law enforcement agencies responsible for maritime security lack requisite adequate funding. Trawlers and other foreign vessels do easily claim to be exercising the submarine and other navigational rights while carrying-out crimes like IUU fishing. Further, the extended nature of the continental shelf and third state rights on it will give room for other forms of maritime crimes like trans-national organized crime, transmission of WMD piracy and armed robbery. More so, a vessel engaging in criminal activity may opt to fly flag of convenience.

At present, maritime insecurity is a major a major problem in Nigeria. Al- 
though Government has been relentless in her efforts to acquire more security equipment through frequent fleet recapitalization, including the purchase of over 250 patrol boats, the equipment remains insufficient for provisions of adequate security for the expanse of Nigerian maritime domain (Defence Web, 2018). The nation is yet to acquire major surveillance equipment Unmanned Aerial Vehicles (UAVs)/Drones needed to enhance the state of security. It therefore follows that since at present, the nation is unable to adequately secure her maritime space, expansion of outer limits of her continental shelf will impose extra security responsibility which the nation is not equipped to meet at present. Although the Senate House of the National Assembly, through the Committee on Marine Transportation, is already taking active steps to see to the expansion of the nations' continental shelf from 200 nautical miles to 350 nautical miles. High Powered Presidential Committee was also set-up for this purpose in 2015 as recommended by the senate in 2013 (The Nation, 2019). This was premised on the exclusive rights to explore and exploit resources in the continental shelf in the extended Continental Shelf which Nigeria will enjoy as a coastal state (Article 77). Nigeria will also enjoy exclusive drilling rights within the Continental Shelf (Article 81). However, this study opines, that expansion of Nigeria's continental shelf as permitted by UNCLOS will further stretch the maritime security equipment and facilities which are currently inadequate to police the Nigerian maritime domain. Further, the various rights granted to other nations within the continental shelf create room for security threats to spread into the Nigerian territorial waters.

\subsection{Limitation on Use of Force for Securing National Maritime Space}

The aim of every law is for it to be enforced, law can only take effect when it is fully enforced. However, one of the most obvious challenges of international law is how to enforce its provisions. Among the most common maritime crimes are piracy and armed robbery against ships, as a result, UNCLOS contains extensive anti-piracy provisions, including measures to be taken by the affected state, inter-state cooperation to combat piracy and the right of hot pursuit. Piracy and armed robbery are crimes. Before a crime can be punished the process between policing, arrest, and prosecution must be properly synchronized and this speaks to enforcement. These processes are not difficult to articulate where the crime in question is a domestic crime. However, the same cannot be said about piracy which is a transnational crime. The process of policing, arrest and prosecution often involves more than one nation. Efforts to combat piracy and armed robbery under UNCLOS are particularly difficult because of the convention's stance against the use of force. Piracy and Armed Robbery against ships are forceful crimes, which often lead to massive loss of lives and huge sums of money. The perpetrators are often combat ready. In contrast, UNCLOS only makes the use of force permissible in limited circumstances, including Article 19(2) (a), 39(1) 
(b) and Article 301. The use of force to combat piracy has been frowned at by the courts and tribunal on several occasions.

In the 1935 P m Alone Case between Canada and US, the use of force to effect searching, seizing and arrest of a Canada ship which was being used as illegal rum runner against prohibition in the US was frowned at by the court. It was held that the US Coast Guard intentionally sank the I'm Alone, as a result the US was found liable for the use of excessive force and required to pay fine. In 1962, the commission of enquiry set-up to investigate the Red Crusader case between the UK and Denmark found that the Danish law enforcement applied excessive force by opening fire on the red crusader, which was engaging in illegal fishing, without issuing required warnings, and in the process endangered lives inboard. The commission was convinced that less force could have been applied to achieve the same result (McLaughlin, 2017). In the $1999 \mathrm{M} / \mathrm{V}$ Saiga case, involving the arrest of M/V Saiga a ship flying the flag of St. Vincent and Grenadines by Guinea, the court had to consider the legality of the arrest. The tribunal considered the circumstances of the case, including the fact that M/V Saiga was an unarmed tanker, it was fully loaded and so had a limited speed limit, it was approached by the Guinea officers who used a speed-boat, fired at MV Saiga without proper notice and any resistance opened fire. Guinea was found guilty of using excess force (Article 123). The principles of enforcement of maritime law expressly prohibit the use of force where avoidable. Where unavoidable the rules of international law and jurisprudence relating to issuance of proper notices and consideration of human rights must be applied. Scholars have variously argued that the use of force in maritime enforcement must be a matter of last resort and must be commensurate (Helmut, 2015).

This study argues that the express prohibition of the use of force in UNCLOS is a major limitation in the Convention which hinders efforts to combat maritime insecurity. Especially in a high risk area like Nigeria, where a vessel or boat has been ascertained as belonging to pirates, the express requirement of the law that such vessel be properly notified and that force should be a matter of last resort endangers the officers of the law enforcement agencies and the crew of the vessel under attack. Pirates in the Nigerian waters are known to be particularly vicious in their attacks and they are often battel ready. On the $9^{\text {th }}$ of March 2019, an offshore supply vessel, DSV E. Francis was attacked by pirates in the Brass Terminal of the Nigerian waters while voyaging through the GoG. The incident was the third of such attach within the duration of 24 hours. The pirates carrying machine guns approach the supply vessel in two speed boats, the crew alerted the captain of their naval security escort which maneuvered he pirates. One pf the pirate boats exchanged fire with the escort vessel while those in the second speed boat proceeded to board the vessel using an elongated ladder. Although the engine was short down the crew led to the engine room for safety, the pirates who boarded the boat went to the engine 
room where they kidnapped five men (Edoza, 2019). In a similar attack in April, four pirates opened fire on an oil tanker along the Bonny River Inner Anchorage, the captain of the tanker signaled their naval guards and this led to a shoot-out between the naval guard and the pirates, in the course of which one of the security guard was injured and the pirates later retreated (Team, 2019). The vicious attacks are not limited to vessels on voyage, anchored vessels are not spared of attacks. In April 2019 pirates attacked a product tanker at the Bonny River inner anchorage in the Niger Delta River. The pirates boarded the vessel and opened fire on the accommodations using an automatic weapon. The NN was notified, two naval boats responded to the distress call, and this led to exchange of fire between the navy and the attackers, although one security officer was injured in process. The Niger Delta is said to the most active piracy zone. The region accounted for six vessel hijack in 2018, 13 of 18 ships were fired upon, 130 of the 141 hostages were taken from the region and 78 of the 83 seafarers kidnapped for ransom were in the region. As a result of the severity of attacks in the Nigerian territorial waters which have spread to the ports, Nigerian ports were recently black listed by the US CG.

Whereas the right of hot pursuit gives room for inter-state cooperation in combating piracy, the restriction placed on the vessel exercising the right from chasing the suspected pirate vessel into the territorial sea of a third state constitutes a major restriction and an escape route for the pirates.

\subsection{Inadequate Funding and Poor Enforcement Capacity}

One of the major challenges undermining efficiency of the UNCLOS security provisions in Nigeria is the problem of inadequate enforcement capacity. The defence sector also suffered from massive neglect and underfunding towards the end of military administration in Nigeria. This had an adverse effect on professionalism, operational efficiency, transparency and accountability in the defence sector till date. Prior to that time, Nigeria had one of Africa's strongest military force, and the $\mathrm{NN}$ was the biggest within the continent (The Maritime Executive). However, the combined effect of under-funding and corruption over the decades has made the NN a shadow of itself. The vessels, equipment and facilities meant for carrying out security functions are poorly maintained, poorly repaired while the recruitment and training of staff are crooked. Frequent embezzlement of funds has left the Navy under equipped, affects the drive of officers to work and increased the openness to corruption. According to the Chief of Naval staff, oil bunkering is difficult to combat and end because security officers often connive with bunkers. The security officers also partake in all manner of illegality including diversion of resources, conniving with and shielding criminal organizations etc. The Joint Task Force (JTF) and the NN principally responsible for maintenance of maritime security are said to be culprits in committing illegality as well. Network of largescale oil bunkers is said to usually pay heavy bribes to the $\mathrm{NN}$ in order 
to be granted free passage (Ostensen \& Brady 2018). There are moles within the NN, Customs and port authorities who supply criminals with information relating to vessels and their cargo. In some cases, armed robbers, pirates and other criminals are issued bills of laden with specification. It is the failure of the security agencies to effectively carry-out their functions that led to the practice of reliance on private security for protection of merchant vessels. The arrangement by the navy to meet the demand for private security through collaboration with private security companies also create more avenue for corruption (Utulu, 2018).

The Nigerian coast line is an expanse of about 420 nautical miles and the nation has an Exclusive Economic Zone and continental shelf of about 200 nautical miles. These are large water resources which can only be adequately secured using adequate modern equipment and facilities. The $\mathrm{NN}$ and other supporting agencies lack the adequate modern equipment needed to properly secure the nations' maritime domain. Although efforts by government to acquire maritime security equipment and properly empower the navy have been continuous since the $20^{\text {th }}$ century. For instance in 2009, the Nigerian Navy had a major expansion and new equipment like two Shaldag Mk IIs was acquired. In 2017, Nigeria acquired One hundred and ten (110) patrol boats, in addition to 35 metre vessels, each equipped with two canons of $12.7 \mathrm{~mm}$ and one canon of $20 \mathrm{~mm}$ each. And 2200 boats were acquired form local boat builders and six new Ocean FPC and 10 rigid hull inflatable boats (Defence Web, 2018). The nation is still acquiring fleets and equipment such as the newly added OPVs, Seaward Defence Boats and 250 Inshore Patrol boats acquired for the NN. Despite these acquisitions, these equipment are not enough to adequately secure the Nigerian maritime domain. Further the nation is yet to acquire modern equipment like Unmanned Aerial Vehicles (UAVs)/Drones and other instruments needed to provide 24 hours security (Ibas, 2019).

The capacity to enforce UNCLOS security provision in the Nigerian waters is also limited by inadequate training of the law enforcement officers and inadequate funding of the concerned agencies. Although the NN collaborates with various other agencies to provide maritime security including Nigerian Maritime Administration and Safety, these agencies are not adequately funded nor are their officers adequately trained to provide maritime security. The frequency and severity of armed robbery in the Nigerian maritime domain call for adequate and periodic training of law enforcement officers. Such security operatives must be able to detect and notice potential security threats, spontaneously respond to such threats and adequately respond to attacks spontaneously and effectively. According to the President, Nigerian Ship Owners Association (NISA), Alhaji Aminu Umar, the officers at present are unable to provide adequate security both onboard and at the respective terminals (Bivbere, 2019). The same fear was expressed by the President of the Nigerian Merchant Navy Officers and Water Transport Senior Staff Association, Engr. Matthew Alalade. According to him, 
Nigeria may be unable to make the most of her maritime resources as a result of inadequate training of graduate cadets. Further, cadets who graduate from various institutions ought to be exposed to sea-time training, in case of Nigeria, the lack of the requisite sea-time training has led several of them to venture into menial jobs as alternative income sources (Oladipupo, 2019). Around October 2018, 32 NN officers were trained as experts in underwater and above-water warfare at the Nigerian Naval Ship (NNS) QUORRA and graduated in 2019. They also acquired specialized training aircraft and helicopter control, submarine and marine operations, ICT, navigation and direction. The population of the $\mathrm{NN}$ is about 15,000 officers, the training of 32 officers in a year is grossly inadequate to meet the demands of securing the Nigerian waters. On a general note, the funds and facilities available for training of the law enforcement personnel are insufficient (Martin 2011). In the absence the requisite periodic training of the law enforcement officers efforts to enforce security provisions of UNCLOS has become futile.

\subsection{Lack of Clarity of Rules of Jurisdiction over Maritime Crimes within Various Zones}

Jurisdiction over maritime security related crime is one issue which lack clear cut definition under UNCLOS and often results in conflict between state parties involves, on several occasions affecting the weight attached to the crime and the punishment resulting the reform. Jurisdiction is the legitimate power of a state to make legal decision over cases, it is an aspect of state sovereignty from which the state derives authority to prescribe and enforce laws. Within the international legal order, Jurisdiction is the competency of a state to put regulations in place and take enforcement steps to ensure compliance with the set regulations within the international legal order (Lenhoff, 1964). International law jurisdiction of a state could be prescribe law and or enforcement law through inscription of penalty for non-compliance. State authority to exercise both prescriptive and enforcement jurisdiction is a derivative of the sovereignty of the state over her territory as recognized by international law, otherwise known as territorial jurisdiction. By extension, a state only has express jurisdiction over actions which took place within her territory, regardless of the persons involved in such acts and lacks jurisdiction over actions which took place outside its territory. Although territorial jurisdiction may be objective or subjective, subjective territorial jurisdiction limits the authority of a state to actions which took place within her territory, while objective territorial jurisdiction extends the authority of a state to actions which took place outside her territory but which has produced effects which spread to the state territory (Akerhust, 1973).

Within the domain of international law, state jurisdiction is also influenced by the nationality principle of extraterritorial jurisdiction. This principle entitles a state to exercise jurisdiction over her nationality, in relation to crimes committed by or against her nationals abroad, or over crimes which affect the 
interest of her nationals. A second but controversial principle of extraterritorial jurisdiction is the universality principle. This principle empowers a state to exercise jurisdiction over crimes which have no direct bearing to its territory or jurisdiction, these are mostly international law crimes like offences under the jus cogens norms (Kraytman, 2005). As far as maritime law is concerned, jurisdiction is rooted in Hugo Grotius' mare Liberum which emphasizes theory of freedom of the high seas and the corollary limited rights of coastal states to exercise jurisdiction over adjourning mainland waters (Thornton 2004).

As regards maritime jurisdiction, the Permanent Court of International Justice (PCIJ) in the 1927 Lotus Case established the principle that although a state may have prescriptive extraterritorial jurisdiction, it has no right to enforce her laws outside her territories, except where it derives the authority and jurisdiction to so do through permissive rule of international custom or convention. However, the court reckoned with the effect doctrine which entitles a state authority to exercise jurisdiction over an offence if the major elements of the offence took place within the state or its effects is seen in the state (Hertogen, 2015). The position in Lotus Case was countered in the 1958 GCLOS which emerged in the aftermath of the World War II, which limits the jurisdiction of coastal state to the territorial waters, internal waters and adjacent coast while jurisdiction on the high seas is vested in the flag state (UNCLOS Article 11). Further variances were introduced to maritime jurisdiction under UNCLOS. In case of an archipelagic state, it has sovereignty over its internal waters, archipelagic waters and adjacent sea belt determined based on the territorial sea. Further, every state has the authority to establish the breath of its territorial sea up to 12 nautical miles from the baseline. A coastal state enjoys full prescriptive and enforcement jurisdiction within its territorial sea (UNCLOS Article 2 and 3). such jurisdiction does not extend to foreign vessels within its territorial sea except where the effect of a crime committed by such foreign vessel extends to the coastal state, disturb the peace and good order of the territorial sea, the assistance of the law enforcement agencies of the coastal state is needed or such involvement is needed to prevent trafficking of narcotic drugs (UNCLOS Article 27). Likewise in the contiguous zone, the coastal state enjoys limited jurisdiction over foreign vessels, exercisable only where there is need to pursue specific violations committed against such vessel within the territorial waters. Since the contiguous is not strictly a territory of the coastal state, the laws of the coastal state are not applicable in the contiguous zone (Shearer, 1986).

Within the EEZ, a coastal state enjoys prescriptive jurisdiction and can therefore enact applicable laws to regulate exploration and exploitation of maritime resources within the zone, the amount of and species of fish which may be harvested and the specification for putting in place artificial island and installations (Shearer 1986). The coastal may also exercise rights over exploration, exploitation, conservation and management of resources within the EEZ, in- 
spect, arrest and institute actions in court to ensure compliance with the law (UNCLOS Article 73). However, because the EEZ may extend up to 200 nautical miles beyond the baseline, both the international law regime of the EEZ and the domestic law regime of the contiguous zone can apply and this often leads to complications.

UNCLOS gives high seas extended definition as inclusive of all parts of the sea which are not the EEZ, territorial sea and internal waters. The high seas jointly belong to all state, hence the principle of freedom of the high seas which extends to freedom over navigation, fishing, scientific research, construction of artificial installation etc. (UNCLOS Article 86). Further, on the high sea, the flag state enjoys exclusive jurisdiction which is both prescriptive and enforcement (UNCLOS Article 92). This is largely debated and often leads to conflict in deciding cases with multiple parties. Argument doctail into whether it is based on the nationality principle, territorial principle, while ITLOS treats the ship and the persons on board as one entity under the jurisdiction of the flag state (Honniball, 2016).

There are several variances that influence state jurisdiction based on the numerous factors capable of shifting maritime boundaries and this often leads to jurisdictional issues which affect efforts settle disputes and combat insecurity. This challenge was properly reflected by the 2012 Enrica Lexie case where two Indian fishermen were killed on board an Indian fishing boat by two Italian navy marines on board an Italian oil tanker, along the coast of the Indian state of Kerala in 2012 (Des Roslers 2013). India and Italy disagreed over jurisdiction over the crime, the nature of the offence ie maritime terrorism or murder and the appropriate adjudicatory forum for settling the dispute (Ghandi, 2013). According to Italy, based on UNCLOS Article 33 and 57, since the place of the incident was outside Indian territorial waters but within her Contiguous Zone, it is beyond Indian jurisdiction and Italian courts are the proper place for adjudication. On the other hand, India claimed jurisdiction based on the nationality of the victims of the crime, and the flag ship on which the crime was committed. Whereas the jurisdiction over the case is not expressly resolved by UNCLOS, it has been argued that by the combined effect of Article 57, 91, 92, 94, 97 and 99 of UNCLOS, both India and Italy can exercise concurrent jurisdiction over the case. Even if this were to be the case, the two states must still agree on the forum of dispute settlement, applicable law during the proceeding, sentencing and enforcement of judgement. There is a possibility of lack of distrust between the two states as Indian will be after maximum punishment and justice while Italy will be after protection of the citizens. Several other cases may also arise where threats to maritime security cannot be adequately addressed as a result of limitations of UNCLOS jurisdictional provisions. Although recourse may be made to diplomatic negotiations, other factors like power asymmetry between states and effect of international politics may still lead to deadlock. 
In the case of Nigeria, the general lack of adequate maritime security equipment and modern equipment for the surveillance the territorial waters constitute a clog to the nations' ability to exercise requisite jurisdiction over her territorial waters as prescribed by UNCLOS. The nation may also not be able to detect any trespass over her maritime space, in good time.

\section{Limitations of UNCLOS Provisions on Piracy}

The Nigerian maritime space has unique importance due to its geostrategic and resource potentials. It accounts for over $70 \%$ of West Africa's crude oil production and falls within the GoG important shipping lane which is an international route serving as an alternative to the Suez canal (Hodgkinson, 2013). Whereas the GoG is a hot spot for maritime piracy, the Nigerian maritime space is a notorious part of the gulf which accounts for $80 \%$ of attacks within the region. The complex romance between piracy and oil legacy in the Niger Delta and the general state of insecurity in the region has led to growth of piracy in the region. The Niger Delta militants specialize in kidnapping for ransom and hostage taking, besides hijacking of vessels and stealing of cargo (Onuoha, 2013). However, the regime for combating piracy and armed robbery under UNCLOS is marred by several limitations which hinder the success of state parties in addressing the issue. Often times, states are reluctant to assume jurisdiction over piracy, due to the options opened to the convicted pirate to seek asylum in the place of prosecution, hence the catch and release practice which keeps pumping pirates back into the system. Further, UNCLOS piracy provision has some inherent limitations which often undermine its efficiency. The requirements that piracy must be committed on the high seas, must be a violent act committed for private ends, must involve two vessels, these limitations undermine the efficiency of UNCLOS piracy provisions and are capable of failing to capture several related attacks as seen in the Achille Lauro in 1985. Although these limitations appear to have been remedied by the SUA Convention and its protocol, the obligation to extradite an offender limits the enforcement jurisdiction of the convention (UNCLOS Article 11).

The 1982 UNCLOS is the constitution of modern maritime practice and administration. There are several provisions of UNCLOS which relates to maritime security both directly and indirectly. UNCLOS set the rule on the delimitation of maritime boundaries which forms the bases of determining the rights and duties of states over the various maritime zones and the resources there in. Delimitation of maritime boundaries also forms the basis of determining state jurisdiction within the various maritime zones which is key to identification of offences and maintenance maritime security. UNCLOS form the basis of settlement of maritime dispute, exploration, exploration and preservation of maritime resources to ensure sustainability. It also sets the two major navigational regime, the transit passage and innocent passage targeted at balancing the rights of coastal states against those of flag states to freely navigate the ocean. However, 
there are several limitations in the provisions of UNCLOS which undermines the effectiveness of maritime security provisions. These were identified as including the restrictive definition of piracy, the lack of clarity of rules for determining criminal jurisdiction of states over maritime crimes and restrictions on the exercise of right of hot pursuit in the territorial sea of a third state thereby creating safe haven for pirates. Although there are other international instruments such as the SUA conventions which attempted to remedy the limitations of UNCLOS, particularly in relation to maritime security, these instruments do not enjoy the same wide acceptance and ratification as UNCLOS and may therefore fail to serve the desired purpose where either if the parties to a dispute is not a party to such agreement.

\subsection{Lack of Express Definition of Armed Robbery against Ships}

UNCLOS Article 101 expressly defines piracy, with the jurisdictional limitation that it occurs on the high seas. The further implication being that any other crime which occurs outside the high seas will not amount to piracy. However, the Convention does not expressly define armed robbery against ships. Meanwhile, this study is based on insecurity in Nigeria's internal waters, which includes armed robbery against ships at the various ports, internal waters, territorial sea and within the Nigerian maritime domain in general. To this end, reliance has to be placed on other international instruments in relation to armed robbery.

Armed robbery on the other hand is any illicit act of violence, detention or deprivation committed against a ship, persons or property on-board a ship, within a states' internal waters, archipelagic waters or territorial sea. It mostly covers all forms of violence committed within domestic maritime space, other than piracy. Whereas piracy is committed on the high sea, armed robbery is committed within territorial waters. Also, piracy is said to be committed for private ends and it mostly involves two ships. On the other hand, the International Maritime Organization (IMO) defines armed robbery against ships as (IMO Code of Practice for Crime investigation of Piracy and Armed Robbery Against Ships, Article 2(2)3)

"1. any illegal act of violence or detention or any act of depredation, or threat thereof, other than an act of piracy, committed for private ends and directed against a ship or against persons or property on board such a ship, within a State's internal waters, archipelagic waters and territorial sea; 2 . any act of inciting or of intentionally facilitating an act described above."

Similar to piracy, armed robbery within the Nigerian waters has remained alarming. The country recorded over nine armed robbery attacks, on berthed ships at various terminals in Apapa between March and April 2018. As a result of the insecurity in the Nigerian ports the US Coast Guard (USCG) withdrew its 
earlier accolades on Nigeria for the commendable level of implementation of the ISPS Code in February 2018. In contrast, sanctions were imposed on Nigeria for lapse in port security by April 2019. This is in response to the incidents of frequent attacks carried out by armed robbers on ships berthed in various port terminals in the country. Within a three-month duration, more than nine vessels were attacked by armed robbers within the Nigerian maritime domain and there were no decisive steps taken by the NPA, NIMASA and other port security agencies to arrest the situation and prevent future reoccurrence. The Nigerian government simply treated the attacks as part of the general state of insecurity in the country. These were not isolated incidents, they exposed the alarming rate of insecurity within the Nigerian territorial waters. Consequently, Nigeria was categorized among nations with poor response to port and ship security (Hellenic Shipping News, 2019).

\subsection{The Non-Applicability of UNCLOS to Third States}

Like other aspects of international law, the operational basis of law of the sea has for several centuries been based on customs which evolved from popular state practices that gradually gained general acceptability thereby becoming obligatory. By the $19^{\text {th }}$ Century, the international community had a consensus on the need to codify those customary norms. Although there were skirmishes of scholarly codification efforts for several reasons, uniform negotiation of multilateral treaties is only traceable to the $19^{\text {th }}$ century. Hence the 1930 Hague Codification Conference and the subsequent three Law of the Sea Conferences organized under the auspices of the United Nations. The 1958 Geneva Conventions are dominantly an accumulation of rules of international customs, part of which were repeated in the 1982 UNCLOS. UNCLOS was enacted to remedy the limitations of the GCLOS, as such operate as a replacement for it. However, the interactions between GCLOS, UNCLOS and customary norms on the law of the sea remain crucial for several reasons, including its impact on preservation of maritime security. The question being: to what extent does UNCLOS provision apply to third states and how does the inapplicable provisions affect security of state parties to the convention.

The rule on applicability of international treaties to third states is set by Article 34 of the 1969 Vienna Conventions on the Law of Treaties, which Provide that

"A treaty does not create either obligations or rights for a third state without its consent," (Vienna Convention on the Law of Treaties, 1969, Article 34)

This is premised on the maxim pacta tertiis nec nocent nec prosunt. This provision was however modified by Article 38 which provides that:

"Nothing in Article 34 and 37 precludes a rule set-forth in a treaty from becoming binding on a third state as a customary rule of international 
law."

The implication of Article 34 and 37 of the Vienna Convention is that where the provisions of a multilateral treaty if based on customary law, such provisions can be applicable to a third state. Thus, the same set of provisions may apply to state parties as a treaty and to non-state parties as customary law. This simply implies that in order for treaty provisions to apply to a third party, it must reflect norms of customary law. The task here is being how to identify customary international law norms in a treaty. It may be difficult to distinguish between pre-existing customary norms and new laws. Thus in order for a treaty provision to be applicable to a third party, it must either reflect pre-existing customary law norms or aid the creation of new customary law rules. The elements for determining whether treaty provisions have assumed the status of new customary law norms were considered in the North Sea Continental Shelf Case (North Sea Continental Shelf Cases) as including uniformity, consistency, opinio juris and time.

On the issue of codifying pre-existing norms of customary law, it is argued that by virtue of the negotiations of UNCLOS, the established principles of customary international law codified in GCLOS may have lost the status of customary law which is the basis of their application to third parties. Another issue is the fact that most of the provisions of the Convention are linked together by virtue of the package nature of the provisions. The provisions of UNCLOS are largely indivisible.

The legal implication being that the provisions of UNCLOS can only apply to a third state in two circumstances. That is there are two classes of customary rights and obligations of UNCLOS which will be unaffected by the package deal, as such may apply to a third state. First, where such provisions are customary law provisions of GLOS which were adopted verbatim from GCLOS without being subjected to negotiation of modification during UNCLOS negotiation. Such as Article 14 (1) GCLOS on Contiguous Zone and Territorial Sea) This is simply because they reflect customary law provisions which existed prior to the negotiation and adoption of UNCLOS. However, where such customary law provisions have changed, especially where they have been exposed to significant changes, they will cease to be applicable to third states. Examples are Article 17 of UNCLOS in relation to the right of innocent passage is a reflection of customary law. However, Article 14 (1) GCLOS on Contiguous Zone and Territorial Sea) However, UNCLOS Articles 18 and 19 have been largely modified. Also applicable to third states are those innovative provisions of UNCLOS which became rules of customary international law by virtue of UNCLOS negotiation. These are provisions that attained the status between the commencement of the conference in 1973 and the adoption of the convention in 1982. This also includes customary law norms that were crystalized between UNCLOS I in 1958 and commencement of the negotiation of UNCLOS III in 
1973.

The argument raised by Hugo Caminos is simply to the effect that any principle expressed under GCLOS which is a reflection of customary international law of the sea and which is adopted verbatim under UNCLOS III provisions constitute customary international law which will become applicable to third states. Such provision can be invoked against third states. On the other hand, any provision of GCLOS which has been modified in the course of UNCLOS negotiations to the extent as to alter its original customary international law form will cease to a customary international law provision binding on third states.

Thus, any security related provision of UNCLOS which is not derived from GCLOS or customary international law cannot be invoked against third states. Therefore actions taken by third states may jeopardize the security of UNCLOS members without any express liability to such third state under UNCLOS.

\section{Limitations Undermining Enforcement of UNCLOS Safety Provisions in Nigeria}

\subsection{Inherent Limitations of UNCLOS}

There are some obvious limitations of the UNCLOS anti-pollution regime applicable to coastal states. These include, the adoption of pollution control subject to classification of pollution rather than zones where such pollution occurs. The fact that pollution control measures of UNCLOS are based on the class of pollution makes the provisions disjointed, confusing and less coherent. Thus, it has been argued that pollution control in the EEZ is complex, easily misunderstood and lacks clarity of the rights of the coastal state. This also causes lack of clarity of rights of coastal state to preserve the marine ecosystem within her jurisdiction in general.

A second factor which makes UNCLOS anti-corruption regime cumbersome is the distinction between jurisdiction and sovereignty (UNCLOS Article 53). A coastal state is granted the sovereign right to explore, use and preserve the living and non-living marine resources within her sea-bed, sub-soil, superjacent waters and EEZ. On the other hand, UNCLOS also establish a jurisdiction regime for states to establish, use and conduct artificial islands, marine scientific research, structures and installations as well as to preserve the marine environment (UNCLOS Article 56). Yet, the meaning of sovereignty and jurisdiction are not defined rather they are left at the discretion of respective states. This gives room to different definition and scope and breeds lack of clarity and uniformity.

\subsection{Failure to Exercise Jurisdiction against Marine Pollution}

UNCLOS basically prescribes the jurisdiction exercisable by respective state parties, but the responsibility is on the states to assume such jurisdiction. Whereas 
Nigeria became a member of UNCLOS in 1986, the Convention was only recently domesticated in 2019. However, the domesticated version of the Act lacks provisions targeted at specifically domesticating UNCLOS provision on vessel conveying dangerous cargo as contained in Article 21 of UNCLOS and prevention of pollution as contained in Article 102-104 of UNCLOS. Nigeria has an obligation to prevent pollution of the marine environment and pollution which may spread from the marine environment. These also include prevention of unlawful importation of toxic or hazardous wastes.

This was reflected in the 1980 incident of shipment of toxic waste into koko, a small fishing village in Nigeria. A total of 3.800 tons of hazardous industrial wastes were shipped into the country in five ships, on agreement with one Sunday Nana on whose land the wastes were dumped upon payment of $\$ 100$ per month as compensation. Upon carrying out laboratory tests, it was found that $28 \%$ of the wastes contained polychlorinated biphenyl (PCB) which is hazardous to health. Five thousand residents were evacuated from the community. However, the chemical adversely affected the health of residents who refused to move and those who had immediate contact with the hazardous chemical which also contained PCBs, dimethyl formaldehyde, and asbestos fibers. The eldest son of the Koko Chief David Okotie became deaf and blind, Sunday Nana had throat cancer which later caused his death and the Nigerian Port Authority workers who assisted in loading the chemicals on the ship back to Italy also suffered chemical burns (Chicago Tribune, 1988).

\subsection{Corruption}

The problem of corruption also exists within other maritime security agencies such as NIMASA. NIMASA is the principal agency of the Nigerian government responsible for enforcement of most regulations containing maritime safety provisions such as the Merchant Shipping Act, NIMASA Act and the Suppression of Piracy and other Maritime Offences Act. However, the efficiency of NIMASA in carrying out its functions without fair or favour is affected by corruption. Corruption is a disturbing phenomenon which affects every sector of the Nigerian economy particularly the public sector. The various safety related functions of NIMASA involve direct relations with stakeholders in the maritime industry, gives room for the agency to have access to huge amount of capital and to be easily compromised. These include inspection of the standard of construction and seaworthiness of vessels, enforcement of provisions relating to manning of ships and training of crew members, taking charge of communications with vessel captain and crew to prevent collision routing of ships etc. In the absence of transparency in the transactions of NIMASA and accountability for funds disbursed, corruption remains a major challenge. In Nigeria today, NIMASA leadership have been variously accused of corruption. In 2018, the former acting Director General of NIMASA Calistus Obi admitted that he diverted N331m meant for building hotel. He was ar- 
raigned by the Economic and Financial Crimes Commission at the Federal High Court in Lagos (Obi, 2019).

In order to effectively implement the safety provisions of UNCLOS as a means of addressing maritime safety and security challenges in Nigeria there is need to eradicate corruption, improve maritime safety and security within the Nigerian maritime domain.

\section{Efforts to Apply UNCLOS Security Provisions in Nigeria}

Nigeria has in place numerous domestic laws which touch on the subject of maritime security within the Nigerian inland waterways, territorial seas and the nation's maritime domain in general. These laws are of major categories. There are some laws that are not directly related to securing the nation's maritime space, but address the trial of offences, conviction and sentencing. These include the Nigerian 1999 Constitution, Admiralty Jurisdiction Act and Admiralty Jurisdiction Procedure Rule 2011 (Ogundipe 2019). For instance, Section 251(1) of the constitution of the Federal Republic of Nigeria vest exclusive jurisdiction over maritime related offences in the Federal High Court.

The second category of laws addresses the immediate implementation and active measures to be taken to enhance maritime security within the Nigerian waters. They include Nigerian Maritime Administration and Safety Agency (NIMASA) Act, The Coastal and Inland Shipping (Cabotage) Act, Nigerian Ports Authority (NPA) Act 1999, Merchant Shipping Act (MSA) 2007 and the National Inland Waterways Authority (NIWA) Act. This second category is more related to the subject matter of this discourse as the laws establish and empower various institutions to enforce relevant maritime laws. The NIMASA Act established NIMASA as the agency of government responsible for the enforcement of the NIMASA Act, the CABOTAGE Act and the Merchant Shipping Act, and international instruments such as the SOLAS Convention, SIPS Code and the ISM Code.

The NIMASA Act designates a whole chapter to safety and security. The Act empowers NIMASA to detain any ship, in any port of place in Nigeria, where there are reasonable grounds to believe that the ship is unfit to sail, unsafe or pose serious security risk. A ship will be deemed to be unsafe to sail if its machinery, equipment or any part thereof is undermanned, if the ship is over loaded or has failed to comply with any other safety and security requirement, including the provisions of the ISM Code or the ISPS Code. Where a person uses for navigation an unsafe lighter, barge or vessel, the person shall be guilty of an offence and upon conviction required to pay a fine not exceeding one million naira and the cost of injury or death resulting to passengers therefrom. The owner of a ship registered in Nigeria, and owned by Nigerian shall ensure that it is safe for navigation and used for safe purposes (Obi, 2019). An owner who fails to discharge these responsibility shall be guilty of a crime and upon being found guilty convicted to pay fine as determined by the Agency and an imprisonment term of 
not less than six months. Liability for non-compliance may also extend to the charter user of the ship and the manager of the ship (NIMASA Act Section 41-42).

Another important provision of the convention which relates to maritime security is the prohibition of shipment of hazardous substances. Before hazardous substances can be shipped, the technical requirements must be met including proper packaging and labelling needed to minimize possible hazard (NIMASA Act Section 45). Other requirements to be met are the supply of the list of the hazardous substances, the stowage plan, the location, measures to handle leakages and requirements to regulate quantity limitations. The Merchant Shipping Act deals with the issue of ship registration, flying of the Nigeria flag and offences relating to it.

However, as far as domestication of international laws which forms the basis of applicability in Nigerian waters is concerned, the relevant ones are those which give effect to UNCLOS and other succeeding international instruments are the Suppression of Piracy and other Maritime Offences Act 2019 and the Maritime (ISPS Code) Regulations 2014 (Decree No 20 of 2013). On the other hand, as far as maritime safety is concerned, the provisions of UNCLOS and prescribed anti-pollution regulations are not expressly provided. However, there are there are domestic regulations which touch on the subject of maritime pollution and maritime safety issues in general. These laws which can be adapted to UNCLOS include the MSA and the NPA Act.

\subsection{The Suppression of Piracy and Other Maritime Offences Act 2019}

In an attempt to combat piracy, armed robbery at sea and other forms of threat to maritime security, the Nigerian President signed into law the Suppression of Piracy and Other Maritime Offence Act (SUPMAO) in 2019 (SUPMOA Section45). The Act is an instrument targeted at giving effect to the provisions of UNCLOS, the Convention for the Suppression of Unlawful Acts against the Safety of Maritime Navigation (SUA) 1988 and its protocols. The provision of the Act applies to ships, aircrafts, other marine crafts, fixed and floating platforms. Thus, it applies to any person on board any of the above mentioned facilities, whether within the Nigerian territorial and internal waters or within international waters or within the territory of other state parties to the relevant conventions on international maritime security.

The first offence identified by the SUPMAO is piracy. In so doing, the Act adopts a definition that is identical with the UNCLOS Definition of Piracy as contained in Article 101. It identified the basic elements of piracy as including an illegal act of violence committed for private ends against the passengers or crew of a private ship or aircraft. The said act must be committed in international waters, or on property which is not within the jurisdiction of any state, and also includes voluntary participation in such act or inciting other to so do such 
acts. Away from the popular generalization of piracy as the major maritime crime, the Act also recognizes other forms of maritime offences including armed robbery at sea and all other forms of illicit acts besides piracy which by be committed by an individual or a group within the Nigerian maritime space. These include hijack of vessels, destruction of a ship, theft of a ship and its cargoes, request for ransom, sharing from proceeds of piracy, causing vessel-sourced pollution, carrying-out any act that amount to threat to life, making false claim of piracy or falsely claiming the occurrence of any other maritime offence recognized by the Act (NIMASA Act Section 4).

An important provision of SUPMOA is the grant of power to prosecute maritime crimes. Where any of the crimes recognized by the Act has been committed, NIMASA is empowered to prosecute the offence upon obtaining the consent of the Attorney General. A crime recognized by the Act may also be prosecuted by the Attorney General, a law officer so designated by the Attorney General or an agent of NIMASA. The Federal High Court is granted exclusive jurisdiction to try offences under the Act whether or not it is maritime related (NIMASA Act Section 5). Where a person is convicted and found guilty of an offence under the Act, regardless of whether the offender carried out the crime using a fire arm or any other weapon shall be sentenced to imprisonment for life and the payment of N50,000,000 (Fifty Million Naira) and shall also be required to restitute the owner. This is an important provision of the Act, the severity of the punishment is targeted at deterring the commission of all forms of maritime crime. This is necessary considering the seriousness maritime crime within the Nigerian maritime domain which is a reflection of the broader picture of the state of maritime insecurity in the Gulf of Guinea. However, there is a disparity presented by the preceding sub-section which provides that where in the course of armed robbery at sea an offender bears a fire arm in his possession, or a BRCN weapon, the offender will be liable upon conviction to 15 years imprisonment (SUPMOA Section 3). This not only inconsistent with the provision of Section 12(1) but it whittles down the previous punishment which aligns with the severity of the crimes and the aim of combating maritime threats within the Nigerian maritime domain.

Another progressive provision of the Act is the recognition of the crime of receiving proceeds of piracy, armed robbery at sea and other maritime crimes. The aim of this provision is to break the chain of groups involved in organized crime by making the punishment applicable to all participants along the chain.

The SUPMOA is indeed a welcomed development worthy of being emulated by other maritime states in the Gulf of Guinea and the West African region in general to combat the problem of maritime insecurity. However, there are certain obvious limitations of the Act which can be improved upon. One of such is the adopting of UNCLOS definition of piracy which by so doing implies that the 
limitations of the definition have also been adapted without improvement. Some of these limitations includes requirement that piracy must be for private ends, that it must include at least two vessels and that it must be for profit motive. In recent times, criminal elements on-board a ship can hijack it, and this may be for other motives such as religious and ideological motives. Another obvious limitation is the failure to define a ship, which call into question whether or not NIMASA has the jurisdiction to punish crimes in relation to oil rigs and vessels used for drilling purposes.

\subsection{Nigerian Ports Authority (NPA) Act 1999}

The 1954 Nigerian Ports Authority Act established the NPA as the government agency in charge of regulation and control of port activities. Since then the Act has been severally repealed and the current Act is the Nigerian Ports Authority Act 2004 (SUPMOA Section 3). Although the current Act is at the verge of being repealed by the Ports and Harbours Authority Bill 2016 which is yet to be passed into law. The Act establishes the NPA as a body corporate and specifies the powers, functions, duties and liabilities of the NPA and also provides rules relating to its internal organization (NPA Act Section 1-7). The NPA Act also provides for certain specific issues such as port operations, pilotage, compulsory land acquisition by the NPA (NPA Act Section 24), control maritime transportation and prevention of pollution within the Nigerian maritime space. The Act establishes a governing board which is responsible for managing the NPA. The tenure, removal and emoluments of the board are also specified (NPA Act Section 3-5).

Structurally, the NPA Act is made up of 128 sections which are further divided into five parts. The functions of the NPA are stipulated extensively to include provision of port facilities and operation of those facilities as deemed appropriate, in a manner that will regulate and improve the use of the various pots in the country (Section 8-9). The Transport Minister is empowered by the NPA Act to at any time declare any place in the country or navigable channel leading into a port as part of the port (NPA Section 30).

Certain provisions of the NPA Act are directly relevant to the subject of maritime security. Subject to the terms in the contract of carriage, the NPA shall be liable for the loss of life or personal injury which occur in the course of the carriage to the extent to which it would ordinarily be liable under the Merchant Shipping Act, as though the ship were registers under the Act and belong to the Authority (NPA Section 30). Before a suit can be commenced against the NPA, the Agency shall be given notice of at least one month, during which it would have been intimated of the cause of action, particulars of claim, name and address of the plaintiff and the relief being sought (Section 81). Certain acts amount to offences under the Act if committed, this includes willful damage of any light house, removal of nay lighthouse, buoy or beacon, rides by, making fasts or running afoul of any lighthouse (Section 92). Other 
offences include entry of a ship into compulsory pilotage district without pilot, willful neglect or carelessness of a pilot which endangers a ship. False declaration of authority to pilot a ship is also a recognised offence under the Act. The NPA also recognise as offence the act of unlawful loosing of moorings, willful sinking of vessels, and entry of a port without lawful authorization (Section 97).

The NPA Act has important provisions which address the subject of maritime security. Including provision on the protection of the domestic maritime environment, control of port entry and usage, control of inter-port transportation designation of various offences and designation of punishment for those offences. However, a major limitation is the need to review its provisions on punishment of the various offences. Penalty recognized by the Act range from 10 to 50 thousand naira fine and 2 years imprisonment (Section 97-119). There is therefore need to review these penalties to reflect the severity of contemporary serious of insecurity within the Nigerian maritime space in order to achieve the aim of deterrence.

\subsection{Merchant Shipping Act, 2007}

The Merchant Shipping Act (MSA) is another important international instrument on maritime practice and administration. The Nigerian MSA was enacted in 2007. It specify the licensing requirements that must be met in order for a vessel to trade in Nigeria. These include registration in Nigeria or abroad, with the exception of a ship licensed to operate solely in Nigerian waters (MSA Part 5). It is an offence to trade without obtaining the certificate of license, a shop owner, agent of charter who so does any upon conviction be liable to pay a 500,000 fine and the ship shall be detained by an officer of customs or any other officer (MSA Section 5(5)).

The flying of flag of convenience is known to be a tool to perpetrate illicit acts. Vessels perpetrating acts like IUU fishing, armed robbery at sea, piracy kidnapping often fly flags of convenience. Thus among the security provisions of the MSA is the failure of a vessel to hoist a flag, as an offence punishable with a fine of not less than 100,000 thousan fine (Section 6(2)). Likewise, flying a Nigerian flag as a flag of convenience to avoid liability (Section $8(2)$ ). The illegal use of a ship's name is also a fine punishable with not less than 100,000 fine (Section 13(5)). The failure to deliver certificate of registration is also an offence punishable by fine of not less than 20,000 naira Section 120(4). The forgery of documents or false declaration can also be an issue of maritime security, whether by presenting documents containing false declaration or as to a person's identity or declaration of interest, a person who is found guilty of the offence may be required to pay a fine of not less of 200 thousand naira (Section 53). Operation of a vessel without a valid seafarer certificate is also an offence punishable with a fine of not more than 25 thousand naira. Likewise is the forgery or fraudulent use of seafarers certificate (Section 90). The MSA takes 
as priority the welfare of seafarers and crew members, as such failure to provide adequate accommodation, water and medical supplies for the crew is an offence (Section 179-182). Other offences are failure to have qualified medical personnel on board or putting passenger in a filthy atmosphere (Section $188(1))$.

Where there is a misconduct on board by a master of cadet which threatens the life of passengers or cause the loss of limbs of a passenger, the cadet or officer so liable will upon conviction be liable to pay affine that is not less than 500,000 or imprisonment for not more than two years (Section195). Another important security related provision of the MSA relates to carriage of dangerous goods. Carriage of dangerous goods can only take place upon compliance with relevant international instruments on maritime security such as the SOLAS Convention, International Maritime Dangerous Goods Code of the International Maritime Organization, the requirement as to package, appropriate notice and disclosure of the features and volume of the goods must be complied with (Section 322-323). On the issue of prevention of pollution, the MSA requires that specific international law instruments on maritime pollution should be complied with (Part XXIII, Section 336). These include International Convention for the Prevention of Pollution from Ships, 1973/1978 and the Annexes thereto; Convention relating to Intervention on the High Seas in cases of Threatened Oil Pollution Casualties, J 969; International Convention on Prevention of Marine Pollution by Dumping of Wastes and Other Matters, 1972; International Convention on Oil Pollution Preparedness, Response and Cooperation, 1990; International Convention on Civil Liability for Oil Pollution Damage 1992; Convention on Limitation of Liability for Maritime Claims, 1976 and the 1996 Protocol thereto; Convention on the Establishment of an International Fund for Compensation for Oil Pollution Damage, and its Protocol of 1992 and Basel Convention on the Control of Transboundary Movements of Wastes and their Disposal, 1989.

It is observable that the MSA contains extensive general provision on maritime practice and administration, applicable to domestic vessels and foreign vessel navigating in the Nigerian waters. It also prescribes the application of other relevant international treaties such as those anti-pollution treaties. A major limitation of the MSA is that most of the prescribed penalty for offences is outdated as such they no longer commensurate with the severity of the offence which they are to punish. However, most of the provisions have been re-enacted into other laws to better meet the need to combat maritime insecurity within the Nigerian maritime space. Some of these laws are the NPA ACT, NIMASA Act, CABOTAGE Act and the most recent Suppression of Piracy and other Maritime Offences Act.

\section{Conclusion and Recommendations}

This study examined the origin of international maritime law and its development over the centuries till its present state. The study also identified the var- 
ious security threats undermining effective maritime practice and administration in Nigeria and examined the challenges undermining the effectiveness of the international maritime regime in combating those threats. The study found that international maritime law originated from customary international law as recognized and applied by the Egyptian, Phoenician and Greek civilization, the earliest codification effort being the Rhodian Sea Law while the first international effort at codifying the law of the sea was the 1958 GCLOS and subsequently 1982 UNCLOS under the auspices of the United Nations. It was also found that security threats have always been a challenge to international maritime practice and administration. In case of Nigeria, there are numerous threats undermining effective maritime practice rendering impracticably the nation's ability to make the most of her maritime resources facilitate development. The study also identified the issues affecting the effectiveness of the international maritime regime in addressing maritime security threats in the Nigerian maritime domain. These include the inherent limitation of the UNCLOS provisions and the country specific socio-economic, political and institutional challenges.

This study concludes that there are problems which developed alongside the laws of the sea and which undermines the effectiveness of the present international maritime regime in addressing maritime security threats at the domestic arena. The study also concludes that Nigeria is unable to maximize the economic potentials of her maritime resources as a result of failure to address the combination of the inherent limitation of UNCLOS and the country specific challenges which make the nation prone to security threats.

\section{Conflicts of Interest}

The authors declare no conflicts of interest regarding the publication of this paper.

\section{References}

Adam, Y. (2007). Contemporary Maritime Piracy in Southeast Asia: History, Causes and Remedies (p. 8). Singapore: Institute of South-East Asian Studies-Yusuf Ishak Institute. https://doi.org/10.1355/9789812307316

Admiralty Jurisdiction Act (2004). Cap A5 Laws of the Federal Republic of Nigeria.

Admiralty Jurisdiction Procedure Rule (2011).

Ahmed, A. (2017). International Law of the Sea: An Overlook and Case Study. Beijing Law Review, 8, 21-40. https://doi.org/10.4236/blr.2017.81003 http://www.scirp.org/journal/ber

Akerhust, M. (1973). Jurisdiction in International Law (British Yearbook of International Law) (p. 154).

Bartlett, C. (2019). IMB: West Africa Remains World's Top Piracy Hot Spot. Safety at Sea, (11th June).

Bin-Hasan, Z. (2007). The Weaknesses of the Hague Rules and the Extent of Reforms 
Made by the Hague-Visby Rules. Malayan Law Journal, 2, 1.

https://papers.ssrn.com/sol3/papers.cfm?abstract id=2234211

Bivbere, G. (2019). Sea Time Training: No Hope in Sight for Graduate Cadets (p. 5). Vanguard, (Lagos, 28 August).

Boyle, A. (2005). Further Development of the Law of the Sea Convention: Mechanisms for Change. The International and Comparative Law Quarterly, 54, 563-584. https://doi.org/10.1093/iclq/lei018

Bueger, C., \& Edmunds, T. (2017). Beyond Sea-Blindness: A New Agenda for Maritime Security Studies. International Affairs, 93, 1293-1294. https://doi.org/10.1093/ia/iix174

Chicago Tribune (1988). Dumped Toxic Waste Imperils Nigerian Port Town. (USA 27 June).

https://www.joc.com/maritime-news/dumped-toxic-waste-imperils-nigerian-port-tow n 19880627.html accessed 18 December 2019

Constitution of the Federal Republic of Nigeria (CFRN) 1999 Section 12(1), (2).

Defence Web (2018). Nigerian Navy Commissions New Vessels.

https://www.defenceweb.co.za/sea/sea-sea/nigerian-navy-commissions-new-vessels/

Edoza, G. (2019). Pirates Kill Naval Officer; Kidnap Five Sailors in the Niger Delta. Ships and Ports, (United Kingdom, 14 March).

https://shipsandports.com.ng/pirates-kill-naval-officer-kidnap-5-sailors-niger-delta

Ekhator, E. (2016). Protection of the Environment and the International Salvage Convention, 1989: An Assessment. Mizan Law Review, 10, 73-99. https://doi.org/10.4314/mlr.v10i1.3

Esposito, M. (2018). The 2017 Oceans beyond Piracy Report. Critical Maritime Routes Programme, 25th May 2018.

https://criticalmaritimeroutes.eu/2018/05/25/the-2017-ocean-beyond-piracy-report

Fawehinmi, A. V. (2000). Nigerian Weekly Law Report (6) (pt 660) (pp. 228-288).

Gedecho, H. (2013). Historical Development of Maritime Law. Abyssinian Law, 20 July.

Ghandi, M. (2013). The Enrica Lexis Incident: Seeing beyond the Grey Areas of International Law. Indian Journal of International Law, 53, 1-26.

Gilpin, R. (2007). Enhancing Maritime Security in the Gulf of Guinea. Strategic Insights, $6,2-14$.

Helmut, T. (2015). Combating Piracy: New Approaches to an Ancient Issue. In L. del Castillo (Ed.), Law of the Sea, From Grotius to the International Tribunal for the Law of the Sea. Netherlands: Brill Nijhoff.

Hertogen, A. (2015). Letting Lotus Bloom. The European Journal of International Law, 26, 901. https://doi.org/10.1093/ejil/chv072

Hodgkinson, S. (2013). Current Trends in Global Piracy: Can Somalia's Successes Help Combat Piracy in the Gulf of Guinea and Elsewhere? Western Reserve Journal of International Law, 46, 145-160. https://doi.org/10.1163/15718085-12341410

Honniball, A. (2016). The Exclusive Flag State Jurisdiction: A Limitation on Pro-Active Port States? The International Journal of Marine and Coastal Law, 31, III 499.

Ibas, I.-E. (2019). Security of the Nigerian Maritime Domain-Issues and Options. Remarks Made at the West African Shipping Summit Held during the London International Shipping Week on 10 Sep. 19, 26 September 2019.

https://www.navy.mil.ng/2019/09/26/security-of-the-nigerian-maritime-domain-issues -and-options

Koh, T. (1985). A Constitution for the Oceans, Statement. In M. H. Nordquist (Ed.), 
United Nations Convention on the Law of the Sea 1982: A Commentary (pp. 11-16). Dordrecht: Martinus Nijhoff.

Kraytman, Y. S. (2005). Universal Jurisdiction-Historical Roots and Modern Implications. Brussels Journal of International Studies, 2, 94.

Lenhoff, A. (1964). International Law and Rules on International Jurisdiction. Cornell Law Review, 50, 1.

Martin, M. (2011). The Troubled Waters of Africa: Piracy in the African Littoral. Journal of the Middle East \& Africa, 2, 65-83. https://doi.org/10.1080/21520844.2011.576452

McLaughlin, R. (2017). Authorizations for Maritime Law Enforcement Operations. International Review of the Red Cross, 98, 465-590. https://doi.org/10.1017/S1816383117000340

Nigerian Ports Authority Act 2004.

Obi, C. N. (2019). NIMASA Ex-Oga Chop 42 Years Jail Sentence. BBC News, (03 June).

Ogundipe, S. (2019). Nigeria Still as Corrupt as before-Transparency International. Premium Times, (Lagos, 29 January 2019).

Oladipupo, S. (2019). Nigerian Cadets Are Half-Baked-Matthew Alade. Nigeriamaritime360.com (19 July).

Onuoha, F. (2013). Piracy and Maritime Security in the Gulf of Guinea: Trends, Concerns, and Propositions. Journal of the Middle East \& Africa, 4, 267-293. https://doi.org/10.1080/21520844.2013.862767

Ostensen, A., \& Brady, S. (2018). Capacity Building for the Nigerian Navy: Eyes Wide Shut on Corruption? Bergen: The U4 Anticorruption Resource Centre, Michelsen Institute.

Raymond, N., \& Ofosu-Boateng, L. (2017) Oil, Risk Analysis Techniques, Maritime Security and Safe Passage in Pirate Infested Gulf of Guinea Waters. Scientific Research, 5, 98-109. https://doi.org/10.4236/jss.2017.512008

Senate Seeks Nigeria's Status on Extended Continental Shelf. The Nation, (19th July 2019).

https://thenationonlineng.net/senate-seeks-nigerias-status-on-extended-continental-sh elf

Shearer, I. A. (1986). Problems of Jurisdiction and Law Enforcement against Delinquent Vessels. International and Comparative Law Quarterly, 35, 320.

https://doi.org/10.1093/iclqaj/35.2.320

The Suppression of Piracy and other Maritime Offences Act 2019.

Thornton, H. (2004). Hugo Grotius and the Freedom of the Seas. International Journal of Maritime, 16, 17. https://doi.org/10.1177/084387140401600203

Treves, T. (1958). Geneva Conventions on the Law of the Sea Geneva, 29 April 1958. Audio-Visual Library of International Law 2020.

https://legal.un.org/avl/ha/gclos/gclos.html

Treves, T. (2020). Geneva Conventions on the Law of the Sea Geneva, 29 April 1958. Audio-Visual Library of International Law 2020.

https://legal.un.org/avl/ha/gclos/gclos.html

Udodiong, I. (2019). Here's why West Africa is becoming the world's piracy hotspot Pulse (14, July).

https://www.pulse.ng/bi/politics/heres-why-west-africa-is-becoming-the-worlds-piracy -hotspot/n93c02z

Ukeje, C., \& Ela, W. M. (2013). African Approaches to Maritime Security-Gulf of Guinea. 
Bonn: Friedrich-Ebert-Stiftung.

United Nations Convention on the Law of the Sea (UNCLOS) (1982). 1833 UNTS 3 (Entered into force 16 November 1994).

Utulu, A. (2018). Corruption Has Become Endemic in Maritime Sector-Nwonu. Independent, (Lagos, 18 February).

Vitzthum, W. G. (2003). From the Rhodian Sea Law to UNCLOS III. Ocean Yearbook Online, 17, 56-69. https://brill.com/view/journals/ocyo/17/1/article-p56 .xml https://doi.org/10.1163/221160003X00050 